\title{
Exploring Possibilities of Project Work to Transfer Pedagogy: Cases of Community High Schools in Nepal
}

\author{
Kamal Prasad Acharya ${ }^{1}$, Milan Acharya ${ }^{2}$, Pitambar Acharya ${ }^{1} \&$ Kalpana Gywali ${ }^{2}$ \\ ${ }^{1}$ Central Department of Education, University Campus, Tribhuvan University, Kirtipur, Kathmandu, Nepal \\ ${ }^{2}$ Department of Health, Physical and Population Education, Sanothimi Campus, Tribhuvan University, Nepal \\ Correspondence: Milan Acharya, Department of Health, Physical and Population Education, Sanothimi Campus \\ Tribhuvan University, Sanothimi, Nepal. Tel: 98-4163-0800. E-mail: milanpanga123@gmail.com
}

Received: February 19, 2019 Accepted: June 1, 2020 Online Published: August 20, 2020

doi:10.5539/gjhs.v12n10p60

URL: https://doi.org/10.5539/gjhs.v12n10p60

\begin{abstract}
This paper discusses the possibilities of student-centered project-based learning in science, health and population subjects of community high school students in Nepal. Besides, it deals with how high school students meaningfully engaged in participatory activities and consequently acknowledge the necessity for creative and active learning. Despite various contextual realities and identities, the study explored few contextually appropriate project methods to transform teaching learning activities in science, health and population subjects in the community high schools. The dogmatic qualitative to student-centred method was applied in this research. Data/information was collected from classroom observation, in-depth interviews and informal conversations. The data from all the sources were analyzed by content-thematic and conversation analysis keeping in minds to explore the possibilities of project work of learning. The study found that students' engagement in project activities as a part of study science, health and population subjects are positive and targeted towards learning competencies. Nevertheless, to apply this method, school head teachers, teachers and local authority related to education need to play vital roles for the effective implementation of project works in the community high schools in Nepal.
\end{abstract}

Keywords: Community school, meaningful engagement, pedagogy transformation, project work

\section{Introduction}

Science, health and population subject teaching and learning in the community schools is based on inflexible approach which is contextually irrelevant in terms of students' achievement and life skills development (Acharya, 2016). Contextualized teachings based on the use of locally available resources seem relevant to impart education for the school level students (Falk \& Dierking, 2018). This process herein pursues a satisfactory association between school science, health and population curriculum to local resources. However, due to the unfortunate linkage of teaching and learning through students' engagement to real life-situation, large numbers of students in the community schools in Nepal have failed to gain life skill-based education for better citizen in the future (Acharya, 2019). Therefore, they have failed to use locally available resources as the means and methods of learning and also to recognize the value of contextual knowledge.

Designing projects in learning science, health and population subjects in high school is a systematic teaching method which encompasses students in learning knowledge and skills through activity assignment, genuine queries and elegant creation (Clandfield \& Hadfield, 2017; Rodwell, 2017). Projects within the meaningful engagement of students as based on challenging questions and making students having a central role in design, problem-solving, decision-making processes (Leggett \& Harrington, 2019), provides students an opportunity to work in collaboration. This kind of learning helps to develop life skills such as collaboration, mutual understanding and trust buildups among friends (Harada, Kirio, Yamamoto, Reman, \& Dickinson, 2015). Meanwhile, Lee, Huh, and Reigeluth (2015) explained that project-based learning organizes learning comprehensively based on challenging problems, which involves students in designing, problem solving, and decision making. Also, Baser, Ozden, and Karaarslan, (2017) argue that collaborative activities help to investigate actions; providing opportunities for independent working and argumentation. It ultimately helps in experiential learning.

In this contextual background, the first and the second authors collaborated with community high school teachers 
and head teachers in Kathmandu, Nepal. There, we introduced project-based learning to explore the possibilities of contextually relevant resources to make science, health and population subjects more meaningful and easy. The schools, we involved in the study were lacking the conceptual clarity in providing meaningful education through project-based learning. They were practicing traditional lecture methods of teaching to deliver the lessons in the high schools. Although teachers were claimed trained and took a nine-month teachers' professional development training, they practiced recitation method in the class.

Project-based learning has some steps as plan, create, and process. In the schools, this approach needs to address the compositions begin with queries or questions, design a plan for the activity, creates a schedule, monitor students' activities, assess the consequence and evaluate learning experiences. Meaningful learning experiences through project activities positively influence students' achievement and originality, and progress inspiration. Students' mentoring is very effective for developing students' skills in a project-based learning environment (Wurdinger, 2016). Teachers can also get feedback on their teaching and learning. Researchers like Lee, Huh, and Reigeluth, (2015) argue, students work together in groups and collaborate on project activities to increases cooperative capabilities characterized with the existence of collaboration among students; and a real-world problem that affects the life of the students is presented for investigation (Kokotsaki, Menzies, \& Wiggins, 2016). Students' participation and activities help to develop creative and cooperative skills as well as problem-solving and argumentation skills. While exploring the project-based learning, students are given a chance to think and create new ideas for learning.

Perhaps the question arises, why should we involve in the research to explore project work for high school students? In the learning of health, population and science subjects in particular, perhaps this model is not new, however, traditional lecture mode of teaching approach emphasizes presenting the results in words and sentences that neglected life skills development. High school students have to develop skills in science, health and population education as this is the age of entering the adolescent period in their life. This condition strikes us to explore the possibilities of project work as a part of teaching and learning at the high school level. Innovative learning activities through project work by the application of resources develop curiosity on the learner, critical thinking, creating participatory, responsible with amusing in the study, use of local resources and knowledge and provides a diverse learning experience through the implementation of various teaching strategies, which is amusing, contextual and meaningful.

To this, the paper addresses the following two research questions to answer:

1. What are the possibilities of exploration of project work in science, health and population subjects for high school students?

2. How do meaningful engagements of students in activities help to develop life skills in science, health and population subjects?

\section{Research Methodology}

This study followed the qualitative research approach, particularly informed through Taylor, Bogdan, and DeVault, (2015). The central objective of initiating project-based learning was to develop knowledge and practice that is grounded in the students' context and collaboration with teachers (Glesne, 2016). Working with students as identical to a particular place, slowly we began to recognize that identities and classroom practices remain significantly determined by context-specific worldviews and philosophical considerations (Illeris, 2018). As researchers, our roles were to assist students and teachers in keeping the dialogue open in in-depth interviews and informal conversations. It enabled us to open ourselves up to a variety of perspectives. We used transformative learning perspectives (Laros, Fuhr, \& Taylor, 2017), and activity-based learning (Stone \& Duffy, 2015) theories as theoretical lenses.

The research on which this article is based, used an exploratory, descriptive and contextual qualitative design (Creswell, \& Poth, 2016), to explore and describe the perceptions and perspectives of students on project-based learning implemented in the community schools.

Two in-depth interviews were taken from high school students and one in-depth interview was taken from the science, health and population teachers. Also, three class observations were done (two science classes and one health and population classes) of $9^{\text {th }}$ grade in the community high schools in Nepal. Informal conversations were done during and after school hours with the teachers and students. To explore the above-mentioned research issues, it was necessary to have face to face communication with students and observe the classes of teachers. While having in-depth interview, all the conversations were recorded. Then adudio record was transcribed based on the judgments of relevance (Creswell, 2015). 


\subsection{Research Ethics}

The research team was conscious on research ethics. Therefore, consent was taken to involve community high school students and teachers for the study and it was expected that they would not be exposed to any significant risks. Furthermore, throughout the in-depth interviews and class conversations, it was emphasized that research participation was voluntary (Iphofen, \& Tolich, 2018) and that the participants were free to withdraw from the study at any moment without having to provide reasons or face any consequences.

\subsection{Research Participants}

Community school science, health and population teachers and $9^{\text {th }}$ graders were the research participants of the study. The first and second authors took two weeks to research the background and contributions of teachers and students in community high schools at Kirtipur, Kathmandu, Nepal. Purposive-convenient sampling was used to identify and select teachers and students, as the intention of this study was to exploring possibilities of project work to transfer pedagogy in the community high schools.

\subsection{Data Collection Procedure}

This study is the outcome of actions, observations and reflections with the determination of project-based learning in science, health and population subjects through students' meaningful engagement and activities. Because of the experience of first and the second authors in research and teaching at school and the university level, this research is rooted to engage students meaningfully in project learning activities outside four walls of the classroom. Yet, I (the first author) am exclusively positioned as an outsider as Bamber (2016) stated that an outsider in a classroom can only observe the classroom situations. Bamber's continuum of positionality, I describe my positionality as an insider in collaboration with other insiders with the value of adopting this research space with new insights to view and hear, as an outsider, look curiously and wonderingly on the world in which I live. It is suggested that engaging students meaningfully in an open natural environment to motivate and explore the knowledge what they have to challenge the deep-rooted styles of adopting knowledge but to explore meaning and opportunities. This belief moved us towards project-based learning to explore opportunities and possibilities for community school students' engagement for learning.

This research is based on exploratory and descriptive design (Creswell, 2017) that explores and describes the perceptions and perspectives of teachers and students on project-based learning to transfer pedagogy in the community high schools in Kathmandu, Nepal. During an in-depth interview, audio was collected and was then transcribed based on our (first and second authors) judgments of relevance (Gee, 2004). Each of the respondents participated in about five periods (one period contains 45 minutes) for project-based activities and about 20 minutes conversation of each group regarding their overall reflections on project work on learning.

Engagement of students in their activities with teachers appears to lead participants to position themselves in various ways. I positioned myself and seemed to be positioned by the research participants a collaborative researcher (which included the role of their facilitator). The first and the second authors see advantages in teachers working with a facilitator because of the lack of time and research methodology skills. However, Illeris, (2016) call researchers' attention to possible power relations between those involved, even when researchers see themselves as being collaborative.

On this point, the literature highlights the effects of reflective practice incorporated into collaborative project-based approach for revising power relations. For example, a teacher collaborative work in Argentina, Bamber (2016) reported that their working collaboratively and reflectively increased autonomy to make further decisions. Students' active engagement in individual level and group reflections in the project learning procedure can lead to gain new knowledge, which was not imposed from outside, through their experiences (Illeris, 2016). In project-based learning, teachers and students reflect on their experiences through reflective practices and take initiative to learn by exercising increased autonomy through collaboration.

\subsection{Data Analysis}

The first and second authors applied content analysis as per the research questions while analyzing the data. In Barkhuizen (2019) view, content analysis is the analysis of the meaning of the structures and expressions contained in a communication. The usual process of practicing content analysis includes constructing, proposing and identifying coding categories for analysis. Creswell (2015) suggests starting with obvious and recurring topics and searching for themes that run through the data. In this study, the second author analyzed the data based on the theme to co-construct knowledge of project-based pedagogy.

Interpretative research (DePoy \& Gitlin, 2019) design was applied to analyze the views of high school students 
and teachers on project-based learning. Firstly, data were transcribed all semi-structured interviews and performed an open coding using the software ATLAS.ti for qualitative analysis, searching the data for interesting features relevant to our interest. Secondly, the first author noted downs the themes of the study (e.g. project-based learning and its effectiveness, students' activities, content analysis and play-way learning). Thirdly, to refine the theme the second author was searching the relationship among the themes. Lastly, the first and the second authors scrutinize the major themes like exploring possibilities of project-based learning, local resources for instructional strategies and the knowledge of students' and teachers' activities. Since all data were collected in the Nepali language, the data analysis was performed in Nepali. During data analysis and write up of the manuscript, the original Nepali quotes were used for as long as possible to prevent losing meaning as a result of translation. The quotes in the final manuscript were translated by the authors and checked by an expert.

The results of the analysis were presented in the form of themes connected to dig-out the exploration of the possibilities of project-based learning in the community high schools in Nepal.

\section{Findings}

Combining themes from the empirical data collection with the conceptual framework, findings were analyzed to explore possibilities of project-based learning in teaching and learning. In this context, views of students and teachers are provided to explore the possibilities of project-based learning in science, health and population subjects in the high school in Nepal.

Student (SB1) (Note 1) in an in-depth interview said like this:

Teachers in the class used only recite the textbook in teaching science, health and population subjects. Teacher was dictating us to note down main points and recite the entire summaries. But, after engaging in the project-based activities, I know, our past experiences were meaningless. Recently, science teachers applied project-based learning in our classroom, engage us in activities, make groups, and provide time to think and discuss and let students discuss teaching contents to explore creative ideas in science, health and population subjects.

Similarly, student (SG3) (Note 2) in the in-depth interview argues like this:

Project work is a student-centered learning method. .....we enjoyed activities, played games in the name of learning, discuss with friends and worded for the common learning goal. Also, we build-up teams and learn for a common task. Our science and health teacher applies only lecture method. Sometimes, my friends sleep in the science class.

One of the teachers (TM3) (Note 3) who is teaching health and population subject at the high school said like this:

Project-based learning to high school students is to dig-out the hidden potentialities. The lecture method of teaching did not let students any chance to explore creative ideas due to the rigid and structured classes. But, in the project work approach of learning, we got time and environment to think more ideas.

In the same line, another teacher (TF2) said:

Project-based learning is a teaching approach that engages students in sustained, collaborative real-world investigations. Students' projects are systematized around a powerful query that demands cooperative activities.

Arguing the view of the teachers, student (SG1) claimed in an informal conversation with the second author and said like this:

For me, a project has different meanings. In the project method of learning, I engage in an activity, explore answer of a project and share with teachers and friends. More interesting thing is that in the project method of learning science and health subjects, friends gather, discuss each other, share ideas and reach the common conclusion based on the question. But the common is that in all these kinds, the answer is seeking through the activities. So, I think, doing activities in search of question is the project for me.

In one of the interviews, a girl (SG2) student said like this:

In every interaction with friends, the teacher makes a group of five-six students. We have more boys than girls in each group. Boys dominate us in doing activities and sometimes they do not listen to ideas. Our (girls) roles are minimal to search the answer to the problem. It is just a fun for us! Learning how to independently engage in activities in the project, especially how to put a question, how to argue, how to come in the conclusion and how to share common understanding is difficult for us in engaging in activities with boys.

Two students in informal conversations said with us in their words like this:

We were eager to learn how to involve in the project to be able to develop our skills needed to learn healthy habits 
and so on. ... The purpose of the project was to realize that teaching and learning do not mean doing away with a structured curriculum and textbooks. Project-based learning complements, builds on, and enhances what we know through regular training. Our teachers do not let us come up with a decision on the work that we do...

One of the teachers (TM1) whose science class was observed and the reflection from this class is summarized in this way:

Exploring the capabilities of students through project-based learning has its roots in experiential education as suggested by John Dewey. Based on Dewey's notion of thoughts, teachers precede his class. I with the complex tasks based on stimulating interest, engage students in design, started involving in problem-solving and making decisions through the investigation of new ideas. Finally, the teacher provided students the opportunity to work relatively autonomously over extended periods.

It was observed that the teachers used the silent and traditional lecture method of teaching without discussion and were asked questions to students. For this, the first author asked, "Which method of teaching do you like"? Teachers' opinion was like this:

I engaged students in activities. For this, I took teacher training of nine months last year. I usually use the lecture method of teaching as it is an easy method of teaching and learning. This practice does not disturb other classes as it is a silent mode of teaching and learning. Students desire this approach as they get reading notes for the examination. The examination system is rigid and thus we compelled to apply the lecture method of teaching and learning to achieve more marks in the examination.

Teachers like activity-oriented teaching as it help students flourish creative and critical ideas and capacities.

In the contrary to the above arguments, one of the teachers (TF2) put his opinion in this way:

Sometimes, project-based learning has few shortcomings if we (the teachers) do not follow the guidelines during its implementation phase. When implementing the project-based learning approach in a large class, it is difficult to manage students in activities. Engaging students in projects increase students 'motivation on the study, but I think it is difficult if the teachers experience difficulty in improving students' motivation, making the students concentrate on learning tasks difficult in helping students to connect new content with their prior knowledge and in performing supportive learning activities professionally.

The teacher (TM1) focused on the advantages of communication skills during project-based learning and he argued like this:

The project method of teaching helps to improve the way of communication among the students. It encourages interaction, argumentation, discussion and reaches to the conclusion. I think this is the most beautiful part of project learning for high school students in Nepal. It also develops the skills of how to explain, how to cooperate and how to convince. This method of teaching helps to fulfill the gap between knowledge (what students know) and thinking (what students intuition), and ultimately students develop the linkage between the knowledge and skills through real activities.

Teacher (TM2) was in favour of students' engagement during project-based learning and argued as:

I know that the school is for the preparation of students to cope with the problems and adverse situations in the actual world, but the teaching methods and evaluation techniques commonly found in schools are seldom relevant to the community outside of the classroom. Students do not have any meaning and essence of the lessons obtained from the lecturing a unit or a content. It is for the single time test and obtains some marks/scores to pass the examination. Our task and the aim of the school are to contribute making an competent citizen with fully equipped skills and knowledge in this challenging world.

From the abouve opinions of studetns, it is found that teachers and students are in the favour of project work of learning while teaching science, health and population subjects in the community high schools in Nepal. Transformation of pedagogy is felt necessary to shift from the chalk and talk method of teaching to activity-based instruction. All the teachers and students focused that project-based learning help to connect real-life context and curriculum implemented by the schools and the nation. Students are encouraged to be independent junior scientists, critical thinkers and life-long learners through project-based engagement in learning. Students argued that the dogma of hesitation, shyness and lack of confidence is overcome through this approach of learning. It is also found thatprobject-based learning is not simply a learning approach; it is a way of working together for the common learning goal. So, it helps to develop social skills like cooperation, collaboration, argumentation and team building. Science teachers argued that this approach of learning have multiple opportunities in-terms of discussion in the class and assessment. Also, the capabilities of students can be developed while working independently. Students 
develop the ability to work with his or her friends and teachers, building teamwork and group skills. It develops the habit of lifelong learning. All these arguments claim that there are the possibilities of transforming dogmatic lecturing into project work to prepare students for the future and build their knowledge on varying background and experiences. It is also recognized that school level students in Nepal build their knowledge on erdifferent backgrounds and experiences. It is also recognized that students have a broader range of capabilities than they have been permitted to show in regular classrooms with the outdated text-book focus.

\section{Discussion}

The study supports to explore the possibilities of project work in high school level students. Even if the findings cannot be generalized throughout the country due to a small study undertaken in one of the community schools in Nepal, it seems that the teachers and students are happy and pleased with the formulation of project-based learning. The first research question was: What are the possibilities of exploration of project work for high school students? To sum up with the results, that teachers should be provided extra and more periods for project-based learning. Meaningful engagement of students is possible for project work in groups if we plan the lesson as per the learning competencies.

Overall, teachers generate and sustain a classroom setting that permits students the best chance to study. Arguing this finding, Acharya, Acharya, and Shrestha, (2020), found that teachers are confronted with classroom problems such as unnecessary conversation during teaching and learning, getting out of assigned place without consent, and throwing substances across the room. Teachers must find creative ways to deal with the issues as well as provide activity-based instruction in the classroom. Connecting this, Read, Frost, Messenger, and Oates, (1999) argue that students' engagement with the nature of the work undertaken, and the challenges involved is an important aspect of project-based learning. Similarly, it was found that the potential of allowing students to construct new knowledge which is action-oriented and socially relevant; of emphasizing collective learning and promoting an inclusive approach to knowledge production and dissemination; and of strengthening critical reflectivity and creativity (Von Kotze, \& Cooper, 2000). In the same line, Kolmos, (1996) found that project work and problem-based learning emphasize the learning process instead of the teaching process if we engage students meaningfully in groups. Livingstone, and Lynch, (2000) found that teachers can powerfully activate students' need to know the content by launching a project with an entry event that engages student interest and initiates questioning.

Furthermore, the second research question was, "How do meaningful engagements of students in activities help to develop life skills in health and population subjects"? The answer of this research question was that when school teachers plan, practice and delivery the content well in an interesting way, students' engagement may increase even they apply traditional method of teaching and learning. Researcher like Acharya (2016) found that students' meaningful engagement in activities is possible if teacher changes their pedagogical practices from the lecture method of teaching to activity-based instruction. Effective implementation needs on-going proficient progress and shifting in learning and teaching for the practice to become part of the academic routine. Teachers' professional development training is most effective when it focuses on specific topics and teaching practices associated with general instructional issues. Linking this finding, community school teachers' activities depend on the ability to identify learning competencies and creating opportunities during the preparation stage of teaching (Acharya, 2018). Likewise, application of project work for the high school students, the engagement is ineffective if the class size is large so that teachers cannot handle at a time by his/her single effort (Acharya, Devkota, \& Dhakal, 2020; Collin, \& Tynjälä, 2003). Similarly, project-based learning helps to improve student learning and achievement (Cheung, Chow, \& Chiu, 2016). In the same way, Baser, Ozden, \& Karaarslan, (2017) argued that interdisciplinary, collaborative problem-based learning was efficient in enhancing students' advanced technological and collaborative skills, as well as exposing them to practices for integrating technology. Furthermore, $\mathrm{Li}$ (2019) found that the individual information seeking to collaborative information seeking fluidly and naturally for activity-oriented learning. We hope that this study could act as a resource in the relevant fields, relevant organizations and schools to engage students meaningfully to transform the pedagogy into activity-based learning.

\section{Acknowledgements}

We would like to thank the students, teachers and parents who actively engaged in dialogue conferences in indepth-interviews and focus group discussions throughout the study period.

\section{Authors' Contributions}

MA and KPA collected, transcribed, translated, interpreted the data and drafted the manuscript. PA and KG provided scholarly guidance and corrected the manuscript. All the authors read and approved the final version of the manuscript. 


\section{Ethical Statement}

Consents were obtained from all the research participants.

\section{Competing Interests Statement}

No potential conflict of interest was reported by the author.

\section{References}

Acharya, M. (2019). Professional development activities for activity-based learning: Case of high school health and population teachers in Kathmandu, Nepal. Research in Pedagogy, 9(2), 143-150. https://doi.org/10.17810/2015.97

Acharya, K. P. (2016). Fostering critical thinking practices at primary science classrooms in Nepal. Research in Pedagogy, 6(2), 1-7. https://doi.org/10.17810/2015.30

Acharya, K. P. (2018). Hands-on, minds-on and hearts-on activities in high school science teaching: A comparison between public and private schools in Nepal. The Online Journal of New Horizons in Education, 8(2), 51-57.

Acharya, K. P., Acharya, M., \& Shrestha, M. K. (2020). Collaborative Learning Practices by Gender: A Case of a Community School in Nepal. International Education Studies, 13(4), 75-83. https://doi.org/10.5539/ies.v13n4p75

Acharya, K. P., Rajbhandary, R. \& Acharya, M. (2019). (Im)Possibility of Learning Science through Livelihood Activities at Community Schools in Nepal. Asian Social Science, 15(6), 88-95. https://doi.org/10.5539/ass.v15n6p88

Acharya, K. P., Devkota, G. P., \& Dhakal, K. P. (2020). Small Change Is Beautiful: Exploring Possibilities of Eco-San on School Garden for Transformative Pedagogy. Higher Education Studies, 10(2), 122-132. https://doi.org/10.5539/hes.v10n2p122

Bamber, P. M. (2016). Transformative Education through International Service-Learning: Realising an ethical ecology of learning. Routledge. https://doi.org/10.4324/9781315684970

Barkhuizen, G. (Ed.). (2019). Qualitative Research Topics in Language Teacher Education. Routledge. https://doi.org/10.4324/9780429461347

Baser, D., Ozden, M. Y., \& Karaarslan, H. (2017). Collaborative project-based learning: an integrative science and technological education project. Research in Science \& Technological Education, 35(2), 131-148. https://doi.org/10.1080/02635143.2016.1274723

Cheung, H. Y., Chow, M. H., \& Chiu, P. K. (2016). How science, technology, engineering, mathematics (STEM) project-based learning improves student learning.

Clandfield, L., \& Hadfield, J. (2017). Interaction online: Creative activities for blended learning. Place (?): Cambridge University Press.

Collin, K., \& Tynjälä, P. (2003). Integrating theory and practice? Employees' and students' experiences of learning at work. Journal of workplace learning, 15(7/8), 338-344. https://doi.org/10.1108/13665620310504828

Creswell, J. W. (2015). 30 essential skills for the qualitative researcher. Place(?): Sage Publications.

Creswell, J. W., \& Creswell, J. D. (2017). Research design: Qualitative, quantitative, and mixed methods approaches. Sage publications.

Creswell, J. W., \& Poth, C. N. (2016). Qualitative inquiry and research design: Choosing among five approaches. Place(?) : Sage publications.

DePoy, E., \& Gitlin, L. N. (2019). Introduction to Research E-Book: Understanding and Applying Multiple Strategies. Elsevier Health Sciences.

Falk, J. H., \& Dierking, L. D. (2018). Learning from museums. Rowman \& Littlefield.

Gee, J. P. (2004). An introduction to discourse analysis: Theory and method. Routledge.

Glesne, C. (2016). Becoming qualitative researchers: An introduction. Pearson. One Lake Street, Upper Saddle River, New Jersey 07458.

Harada, V. H., Kirio, C., Yamamoto, S., Reman, J., \& Dickinson, G. K. (2015). Project-based learning: rigor and relevance in high schools. School library management, 157.

Illeris, K. (2016). How we learn: Learning and non-learning in school and beyond. Routledge. 
https://doi.org/10.4324/9781315537382

Illeris, K. (Ed.). (2018). Contemporary theories of learning: learning theorists... in their own words. Routledge. https://doi.org/10.4324/9781315147277

Iphofen, R., \& Tolich, M. (Eds.). (2018). The SAGE handbook of qualitative research ethics. Sage. https://doi.org/10.4135/9781526435446

Kokotsaki, D., Menzies, V., \& Wiggins, A. (2016). Project-based learning: A review of the literature. Improving schools, 19(3), 267-277. https://doi.org/10.1177/1365480216659733

Kolmos, A. (1996). Reflections on project work and problem-based learning. European journal of engineering education, 21(2), 141-148. https://doi.org/10.1080/03043799608923397

Langer, A. M. (2017). Book Review: Understanding and promoting transformative learning: A guide to theory and practice. https://doi.org/10.1177/1541344617695885

Laros, A., Fuhr, T., \& Taylor, E. W. (Eds.). (2017). Transformative learning meets Bildung: An international exchange. Springer. https://doi.org/10.1007/978-94-6300-797-9

Lee, D., Huh, Y., \& Reigeluth, C. M. (2015). Collaboration, intragroup conflict, and social skills in project-based learning. Instructional Science, 43(5), 561-590. https://doi.org/10.1007/s11251-015-9348-7

Leggett, G., \& Harrington, I. (2019). The impact of Project Based Learning (PBL) on students from low socio economic statuses: a review. International Journal of Inclusive Education, 1-17. https://doi.org/10.1080/13603116.2019.1609101

Li, X. (2019). Collaborative information seeking in library makerspaces: An exploratory study. iConference 2019 Proceedings. https://doi.org/10.1080/13603116.2019.1609101

Livingstone, D., \& Lynch, K. (2000). Group project work and student-centred active learning: Two different experiences. Studies in Higher education, 25(3), 325-345. https://doi.org/10.1080/713696161

Mulder, A., \& Van Den Berg, B. (2019). Learning for Life: An Imaginative Approach to Worldview Education in the Context of Diversity. Wipf and Stock Publishers.

Read, S., Frost, I., Messenger, N., \& Oates, S. (1999). Bereavement counselling and support for people with a learning disability: Identifying issues and exploring possibilities. British Journal of Learning Disabilities, 27(3), 99-104. https://doi.org/10.1111/j.1468-3156.1999.tb00097.x

Rodwell, J. (2017). Activity-based Training Design: Transforming the Learning of Knowledge. Routledge. https://doi.org/10.4324/9781315263380

Stone, G. A., \& Duffy, L. N. (2015). Transformative learning theory: A systematic review of travel and tourism scholarship. Journal of Teaching in Travel \& Tourism, 15(3), 204-224. https://doi.org/10.1080/15313220.2015.1059305

Taylor, S. J., Bogdan, R., \& DeVault, M. (2015). Introduction to qualitative research methods: A guidebook and resource. Place(?): John Wiley \& Sons.

Von Kotze, A., \& Cooper, L. (2000). Exploring the transformative potential of project-based learning in university adult education. Studies in the Education of Adults, 32(2), 212-228. https://doi.org/10.1080/02660830.2000.11661431

Wegerif, R., Li, L., \& Kaufman, J. C. (Eds.). (2015). The Routledge international handbook of research on teaching thinking. Routledge.

Wurdinger, S. D. (2016). The power of project-based learning: Helping students develop important life skills. Rowman \& Littlefield.

\section{Notes}

Note 1. SB1 means student boy-1

Note 2. SG3 means student girl-3

Note 3. TM3 means teacher male-3 


\section{Copyrights}

Copyright for this article is retained by the author(s), with first publication rights granted to the journal.

This is an open-access article distributed under the terms and conditions of the Creative Commons Attribution license (http://creativecommons.org/licenses/by/4.0/). 